THURSDAY, JUNE I7, r9I5.

\section{THE MOBILISATION OF SCIENCE}

I a letter to the Times of June Ir Mr. H. G. Wells gives utterance to a plea which, unheeded in days of peace, may awaken a sympathetic response while the stress of war is upon the nation. In asking that faith in the man behind the gun shall not be made any longer an excuse for providing him with fewer or inferior weapons, he invites political leaders and the War Office to make the fullest use of scientific men and method in the conduct of the war. $\mathrm{He}$ asks for the appointment of an acting sub-Government of scientific and technically competent men which will organise our utmost resources of scientific knowledge and promote the employment of the most effective means of dealing with the enemy.

There are signs that things are moving in the direction which Mr. Wells indicates as the road along which triumph must be assured, and his letter should hasten the organisation of the scientific forces which will assist to this end. The publication of the total number of casualties during the last ten months ought to convince the nation that this war is one in which we cannot afford to give odds; and that all the force of scientific ingenuity and scientific organisation must be concentrated upon the military and naval operations. There are hundreds of men of science in the country whose energies and expert knowledge are not being effectively used. We should possess a scientific corps, with men investigating at the Front as well as at home, instead of one or two committees advising officials as to possible means of offence or defence. When a man of science of such distinguished eminence as Prof. J. A. Fleming can say, as he does in the Times of June ${ }^{5}$, that after ten months of scientific warfare he has never been asked to co-operate in any experimental work or place any of his expert knowledge at the disposal of the forces of the Crown, though he is anxious to give such assistance, it is evident that the people in authority cannot understand the value of the scientific forces which it cheerfully neglects. Not a day passes but we are asked by men of science how they can devote their knowledge to national needs; and there is no ready answer. The organisation of the scientific intellect of the country is essential, yet almost nothing has yet been done towards its accomplishment.

It seems necessary, in considering how national NO. $238 \mathrm{I}$, VOL. 95] needs may be met, to separate the invention of new methods of offence or defence from an increase in the supply of high explosive shell which has loomed so large in the newspapers. The novelty of the conditions and the unconventionality of the methods employed in this war carry the first problem outside the grooves in which naval and military engineers have hitherto worked; and the united efforts of civilians and Service men will be required for its solution. The necessity has arisen for surveying the whole scientific field to discover methods of destruction which we may use ourselves or from which our men look to us for protection. It is not enough that the Government should call in a scientific expert to advise in respect of what has occurred; they must be ready to meet it when it does occur. Moreover, such intelligent anticipation ought not to be the special property of one department, and departmental rivalry or indifference ought to be smothered at birth by the appointment of a National Committee with a free hand and ample funds for experimental work.

Such an arrangement is the more necessary in order to prevent the diffusion of effort over too wide a field. Some men are already engaged upon investigations of first-rate importance and yet unconnected either with industry or war; and others are doing work upon which the maintenance of trade depends. It should be possible to secure a sufficient number of men of adequate standing without encroaching in any way upon those we have mentioned. For the war will bring its aftermath of international competition, and we might as well lose as neglect to prepare for it. We plead, therefore, with Mr. Wells for a central organisation which shall direct into the most useful channels that mass of scientific knowledge and skill which is only waiting to serve the country's need.

But valuable as the work of such a committee might be, it would not obviate the desirability of using technically trained men to a far greater extent than is at present attempted, in increasing the output of the ordinary munitions of war. The problem before the new Minister is a dual one, and the two factors are labour and organisation. No man can do more than Mr. Lloyd George in persuading the workmen as a body to recognise the importance of unity and the danger which arises from industrial disputes; and every speech he delivers is both an inspiration and a warning. But it remains to be seen how far he will be able to secure that smoothness and efficiency of 
administration that is so completely the need of the hour.

The intention of the Minister has been pretty clearly expressed. Production is to be speeded up by using at first the most perfectly equipped shops, and by drawing labour and machines from those less fully qualified to undertake the work. It is to be hoped that an effort will be made to work three shifts in the twenty-four hours. There seems to be no reason why the students in the scientific and technological faculties of the universities and older boys in public schools should not be mobilised for this purpose. The greater number of jobs are carried out on automatic machines, the control of which can be learnt in a fortnight or less. The main object, however, is that the most efficient and economical methods of production must be adopted; the small shop, therefore, must stand out; and the individual must express his patriotism in co-operative effort.

Not a great deal of consolation is to be derived from the administration of local committees constituted by a careful balancing of interests and "municipalised" by the presence of the chief magistrate. If the local employers, managers, or foremen are giving the most effective service in their own works they will have little time for attending committees. A committee is as effective in affording opportunity for personal differences as it is for securing unanimity as to method and aim. The more such bodies are used in an advisory, and the less they are used in an executive capacity, the happier will be the resilt of their efforts. For getting things done one autocrat is worth twenty committees, provided that he has common sense and is neither a politician nor a lawyer who regulates action by precedent.

The work of organising our scientific and technical forces should not be put into the hands of men whose knowledge is limited to the etymological derivation of the names of things required--at least not in time of war, and it is imperative to consider whether the real resources of technically trained men have been tapped. A great many have entered the army and have been drafted into regiments where their specialised knowledge is of little use. Even then the fact that they can write has resulted in their being burdened with clerical work, which could as easily be done by women. But there are many men who for more or less adequate reasons are not in uniform and are only awaiting the call to industrial service. In comparison with previous wars the present conflict is not a war of men so much

NO. $238 \mathrm{I}$, voL. 95] as a war of guns and ammunition, and if we are to hasten that end which we believe to be inevitable, we must concentrate every element of scientific knowledge and technical skill into its prosecution.

Scientific discovery, mechanical invention, and a highly technical organisation as employed by the Germans are only to be beaten by similar forces arrayed against them. It is not a time to say what ought to have been in the past, but what should be now and in the immediate future. We know that up to a certain point the scientific resources of the country have been drawn upon, but beyond the fact that one man is working at explosives, another at the Royal Aircraft Factory, and a third is testing for the Admiralty, we want to feel that these are only details of a wider scheme so perfect in its organisation that the full effect of our forty-five millions of people is brought to bear upon the enemy. Many people would sleep more peacefully if they knew that every technically trained man in the universities, university colleges, technical institutions, and in the Government Departments was not doing his "business as usual," but making it his special business to provide the nation with the scientific material and machinery by which alone can our forces achieve success in the present conflict.

\section{MODERN ELECTRICAL THEORY.}

The Electron Theory of Matter. By Prof. O. W. Richardson. Pp. vi+6ra. (Cambridge: At the University Press, I9I4.) Price I8s, net.

THIS book is based on a series of lectures I delivered by Prof. Richardson at the University of Princeton, and gives a general survey of the electron theory. The book starts with an account of the elementary principles of the theory of electricity and magnetism, and a discussion of phenomena which can be explained on the general Maxwell theory. From this we are gradually led to the discussion of such phenomena as dispersion and selective absorption, which have first found satisfactory explanations on the electron theory. Next follows a closer account of the theory of the mechanics of electrons, containing detailed considerations of the problems of electromagnetic mass, the radiation from an accelerated electron, and the properties of moving systems. This part ends with a brief account of the principles of the theory of relativity. After this we return again to the consideration of the general properties of matter, and the results deduced in the preceding chapters are 